\title{
Odnos prebivalcev zahodnega dela Šaleške doline do pokrajinskih virov
}

\author{
Natalija Špeh \\ ERICo Velenje, Inštitut za ekološke raziskave, Koroška 58, \\ 3320 Velenje, Slovenija \\ e-mail: natalija.speh@erico.si
}

\section{Izvleček}

V pokrajini, pod površjem katere so leta 1986 načrtovali odkopavanje surovinskega vira - lignita, in načrte dokončno opustili šele januarja 2002, smo ugotavljali odnos prebivalcev do pokrajinskih virov ${ }^{1}$. Potencialno prizadeti prebivalci so tako $v$ urbanem kot podeželskem delu območja izrazili enotno mnenje proti načrtovanemu posegu.

Ključne besede: socialno-geografski vidik, pokrajinski viri, ugrezninsko območje, Šaleška dolina

\section{Response of inhabitants of the Western part of the Šalek Valley to the landscape sources}

\begin{abstract}
Lignite minning was planned under the studied area in 1984. However it was rejected in 2002. The research project was founded in 1999) on the relation of the potentialy affected inhabitants to the landscape sources (especially the lignite). The results revealed almost uniform public opinion against the planned excavation, which was expressed by both rural and urban population.
\end{abstract}

Key words: inhabitants' response, landscape sources, subsidence area, Šalek Valley

\footnotetext{
${ }^{1}$ V prispevku uporabljeno izrazoslovje pokrajinskih virov ustreza pokrajinotvornim dejavnikom, t.j. skupku dejavnikov (naravnih in družbenih), ki vplivajo in oblikujejo določeno pokrajinskoekološko enoto (Kladniks sod., 2001: 403). Zaradi funkcijskega metodološkega pristopa ter z vidika dejavnosti človeka se nam je v pričujočem prispevku namesto obravnave dejavnikov pokrajine zdela primernejša uporaba izraza pokrajinski viri.
} 


\section{UVOD}

Obravnavano območje potencialne degradacije pokrajinskih virov (dejavnikov) na površju obsega okrog 400 ha. Nahaja se v zahodnem delu Šaleške doline in zavzema podeželska naselja Topolšica, Ravne in Florjan ter S- in SZ-del mestnega naselja Šoštanj.

Vsak prostor sestavljajo ekološka komponenta (naravni viri) in človeške prvine (družbeni in gospodarski viri), ki se med seboj prepletajo. Zato ga moramo po Prosenu (1993) obravnavati celostno. Vsak pokrajinsko-ekološki sistem zajema določene pokrajinske vire, ki so temeljni za postavitev razvojnih možnosti in ciljev celostnega regionalnega razvoja izbrane pokrajine: prebivalstveni, poselitveni, kmetijski in gospodarski viri, rekreacijsko-turistični, naravni vir ipd. (slika 2). Zdravo bivalno okolje ter ohranjeni in vitalni regionalni naravni viri so vse bolj pomemben razvojni lokacijski dejavnik (Plut, 2002).

Zanimal nas je odnos prebivalcev, ki bi jih morebitno nadaljnje širjenje pridobivalnega prostora velenjskega premogovnika prizadelo, do posameznega pokrajinskega vira na obravnavanem območju. Med naravnimi viri smo izpostavili surovinski vir, ki je bil hkrati povod za raziskavo samo, upoštevali pa smo še prebivalstvene, poselitvene, infrastrukturne, gospodarske in turistično-rekreativne pokrajinske vire.

Slika 1: Površinski pokrajinski viri obravnavanega območja leta 2000 (objekti nekdanje šoštanjske usnjarne v ospredju so danes že porušeni)(fot: N. Špeh)

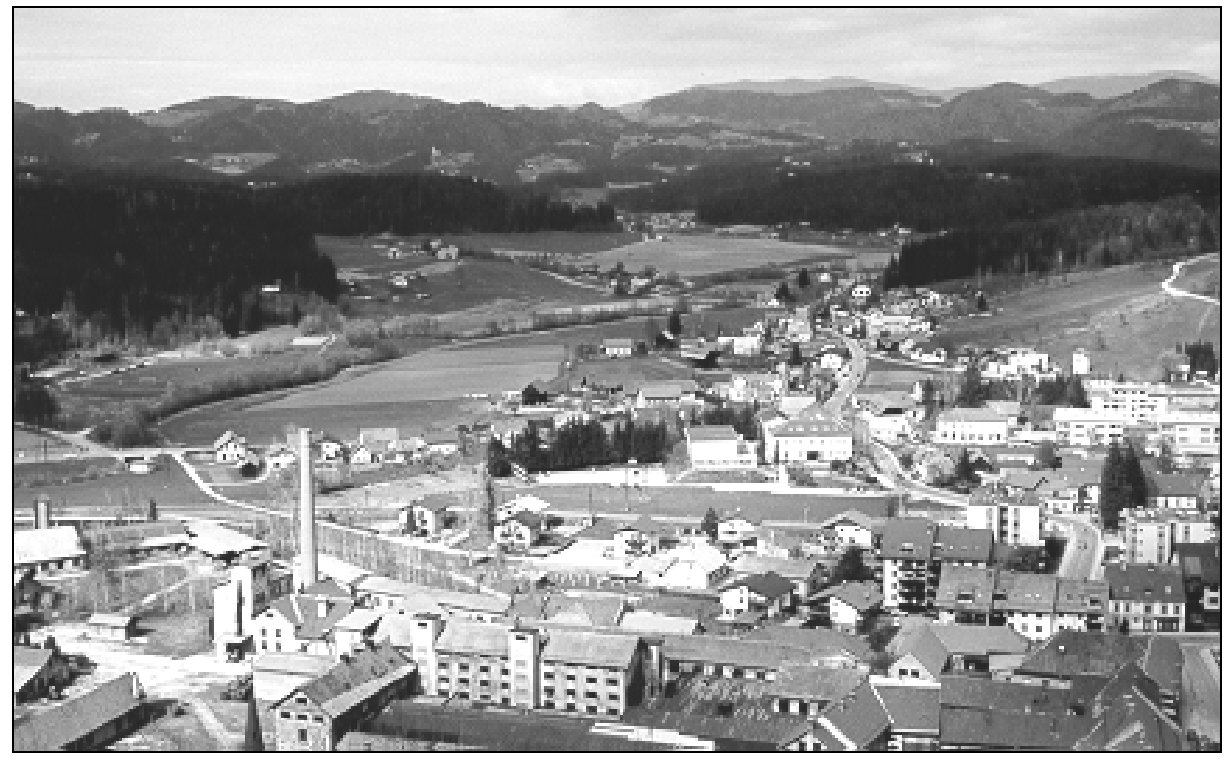


Temeljno tradicionalno členitev na mestna (urbana) in kmečka (agrarna) naselja je novejši razvoj že močno relativiziral. Množična urbanizacija je spremenila podobo poselitve in ustvarila številne nove prehodne oblike, ki so marsikje v pokrajini na obrobju mest celo dominantne. Zato je bolj smiselno uvrščati nova zunajmestna, preoblikovana in socialno preslojena naselja med ruralna (podeželska). Precej sedanjih urbanih naselij se je šele v zadnjem stoletju ali celo šele v zadnjih desetletjih razvilo iz vasi (Kokole, Ve., Kokole, Vl., 1998), npr. naselje Florjan na obravnavanem območju.

Slika 2: Pokrajinski viri kot možnosti regionalnega razvoja in napredka posameznega pokrajinsko-ekološkega sistema (po Špesovi, 1998 in Prosenu, 1993)

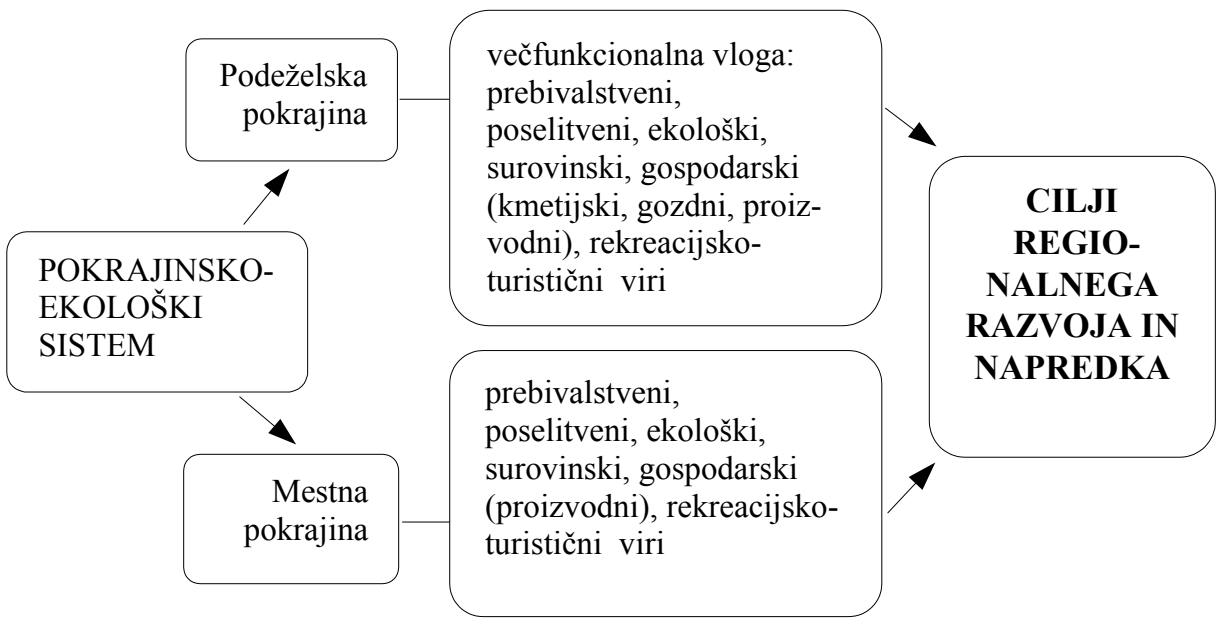

Ugotavljali smo, kako so stališča prebivalcev odvisna od urbaniziranosti njihovega bivalnega in delovnega okolja. Zato smo pripravili vprašalnik ${ }^{2}$ posebej za mestna in podeželska gospodinjstva in dobili mnenja članov (starejših od 15 let) 98 potencialno prizadetih gospodinjstev $\mathrm{v}$ dveh različnih pokrajinah (podeželski in urbani), kar predstavlja dobrih $20 \%$ vseh gospodinjstev na obravnavanem območju, ki bi bila oškodovana z izgubo bivalnega prostora ali zemljišč.

\footnotetext{
${ }^{2} V$ okviru terenskih vaj je anketiralo 35 študentov 3. in 4. letnika oddelka za geografijo na Filozofski fakulteti Univerze v Ljubljani, usmeritev Varstvo geografskega okolja. Anketiranje je potekalo 2. in 3. junija 1999.
} 
Glede na število opravljenih anket menimo, da lahko rezultate raziskave posplošimo na celotno prebivalstvo ogroženega območja. Zbrali smo 49 rešenih vprašalnih listov za vsak tip naselja. Reprezentativnost vzorca smo preverili s primerjavo družbenih kazalcev oz. filtrov (Špes, 1998) - starostna, izobrazbena in zaposlitvena struktura - s podatki za cela naselja. Izkazalo se je, da sestava našega vzorca bistveno ne odstopa od povprečnih vrednosti, ki veljajo za naselja na splošno.

\section{IZHODIŠČA}

Paradigma sonaravnega razvoja, ki poudarja nujnost varovanja okolja pri gospodarskem razvoju, je vnesla nove, širše razsežnosti v pojmovanje kakovosti človekovega okolja (Plut, 1996). Pri proučevanju medsebojnega součinkovanja in sovplivanja med posameznimi sestavinami okolja nas poleg pokrajinskih učinkov človekovih posegov v okolje zanimajo tudi posredni vplivi degradiranega okolja na človeka. Zanima nas, kako različne skupine prebivalstva sprejmajo okolje, kaj vpliva na njihov odnos oz. kakšni so prostorski učinki njihovega odzivanja. Dejavniki, ki vplivajo na različno razumevanje in dojemanje okolja ter oblikujejo različne predstave o okolju in ljudeh, so združeni v skupino socialno-geografskih filtrov: starostna, izobrazbena, poklicna sestava in ekonomski položaj prebivalstva, stopnja neposredne odvisnosti od naravnih virov ...) (Špes, 1998).

Naravno okolje je za nas vir in nenehno spreminjajoča se podlaga, na kateri si človek in družba v zgodovinskem razvoju glede na zahteve danega obdobja ustvarjata svoje življenje, s tem pa tudi svoje življenjsko okolje (Mikulik, Buček, Špes, 1989).

Zakonodaja (Uredba o vrstah posegov..., Ur. 1. RS, št. 66/96) obvezuje načrtovalce in izvajalce podzemnega (jamskega) pridobivanja energetskih in nekovinskih rudnin in kamnin, kjer se pričakuje posedanje površine in le-ta zavzema na površju 10 ha ali več, s pripravo elaborata o presoji vplivov na okolje. Vsebina poročila o strateški (celoviti) presoji vplivov na okolje pa mora zajemati tudi socialno problematiko (Strateške presoje..., 2000) oz. odnos potencialno prizadetih prebivalcev do načrtovanega posega. Tudi pripravljeni programi okoljevarstvenih ukrepov (NPVO, 1999) predvidevajo aktivno vlogo javnosti (izobraževalni programi, različne oblike obveščanja in usposabljanja). Posamezniki, skupine in organizacije morajo sodelovati pri postopkih ocenjevanja vplivov na okolje ter biti seznanjeni in vključeni v politično ravnanje in odločanje skupnosti, še posebej, ko gre za potencialne vplive in učinke na prostor, kjer skupnost živi in dela (Taking Action, 1995). To ni pravica do abstraktnega okolja, temveč je to pravica do varovanja lastnega življenjskega 
prostora, ki je od leta 1972 vključena v mednarodne pogodbe in deklaracije (Priročnik o udeležbi ..., 1994).

Eden pomembnejših mednarodnih okoljskih dokumentov Agenda 21 (Rio de Janeiro, 1992) ugotavlja, da je pri doseganju trajnostnega in sonaravnega razvoja bistvena udeležba javnosti pri sprejemanju odločitev. Podobne so zahteve Aarhuske konvencije, konvencije o dostopu do informacij, sodelovanju javnosti pri odlocanju in dostopu do varstva pravic v okoljskih zadevah (Enovice UMANOTERA 073/02).

\section{ODNOS POTENCIALNO OGROŽENIH PREBIVALCEV DO SPREMEMB KVALITETE POKRAJINSKIH VIROV}

Že odgovori na uvodna anketna vprašanja so nakazali pritisk potencialne ogroženosti posega na pokrajinske vire obravnavanega območja, saj sta dve tretjini naselij dajali vtis o stagnaciji.

\subsection{Odnos prebivalcev do nekaterih potencialno degra- diranih pokrajinskih virov obravnavanega območja}

Diagram 1: Mnenje urbanega in podeželskega prebivalstva o potencialno degradiranih pokrajinskih virih (v\%)

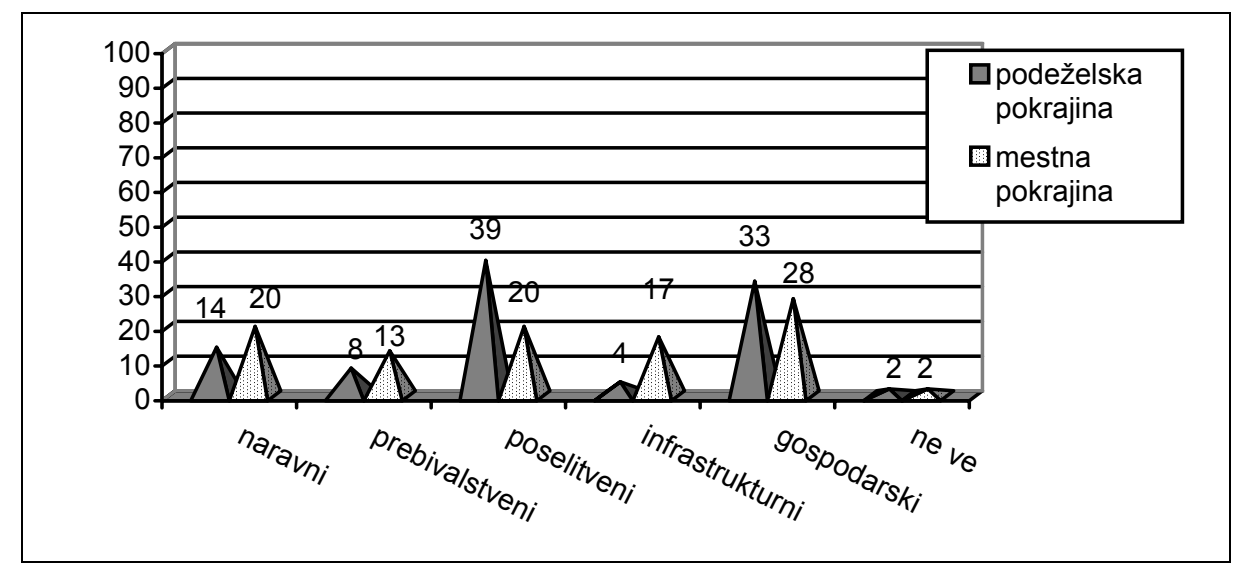

Med odgovori o potencialnih posledicah načrtovanega posega na pokrajinske vire so anketirani največkrat omenili degradirane poselitvene vire. Verjetno je bil ta odgovor najpogostejši zaradi očitne in razsežne dosedanje degradacije poselitvenih virov na območju aktivnega pridobivanja lignita (potopljeni deli 
naselij Škale, Družmirje, Preloge, več kot 1500 že preseljenih prebivalcev). Zanj se je odločilo $39 \%$ vprašanih v podeželskih naseljih in $20 \% \mathrm{v}$ urbanih. Uničenje gospodarskih (proizvodnih, kmetijskih) virov pokrajine so izpostavili prebivalci urbanih predelov kot najpomembnejšo posledico (28 \%), ki bi jo povzročil poseg nadaljnjega odkopavanja. $\mathrm{V}$ podeželskih naseljih se je zanj opredelilo $33 \%$ anketiranih. Naslednji večji vpliv bi imel potencialni odkop na krčenje prebivalstvenih virov; po mnenju vprašanih $\mathrm{v}$ urbanih gospodinjstvih $13 \%$ ter $8 \%$ na podeželju. Naslednji možen degradacijski učinek po pomembnosti je razvrednotenje naravnih virov; izpostavilo ga je $12 \%$ anketiranih na podeželju in $13 \% \mathrm{v}$ mestu, kjer je 8 vprašanih (17\%) poudarilo uničenje infrastrukturnih virov. V podeželskih naseljih so to posledico omenili $4 \%$ anketiranih.

\subsection{Odnos prebivalcev do potencialne degradacije surovinskega vira $v$ obravnavani pokrajini}

Ugotovili smo precej poenoteno odzivanje potencialno prizadetih prebivalcev celotnega proučevanega območja proti predlogu o nadaljnjem odkopu lignita; $81 \% \mathrm{v}$ urbanih in $86 \% \mathrm{v}$ podeželskih naseljih. Višji delež v podeželski pokrajini ne glede na katerikoli socialno-geografski kazalec (starost, izobrazbo, poklic) je lahko posledica dejstva, da ima njihovo bivalno okolje večfunkcionalno vlogo, saj predstavlja hkrati njihovo delovno okolje (delno), okolje bivanja in prostočasnih dejavnosti. Pri podeželskih prebivalcih se tako izraža močnejša navezanost na naravo oz. posest (obdelovalna tla, gozd, živina), saj je njihovo delo in življenje bolj odvisno od njih in zato intenzivneje sprejemajo vplive iz okolja, še zlasti negativne.

Diagram 2: Odziv prebivalcev na predlog o krčenju surovinskega vira

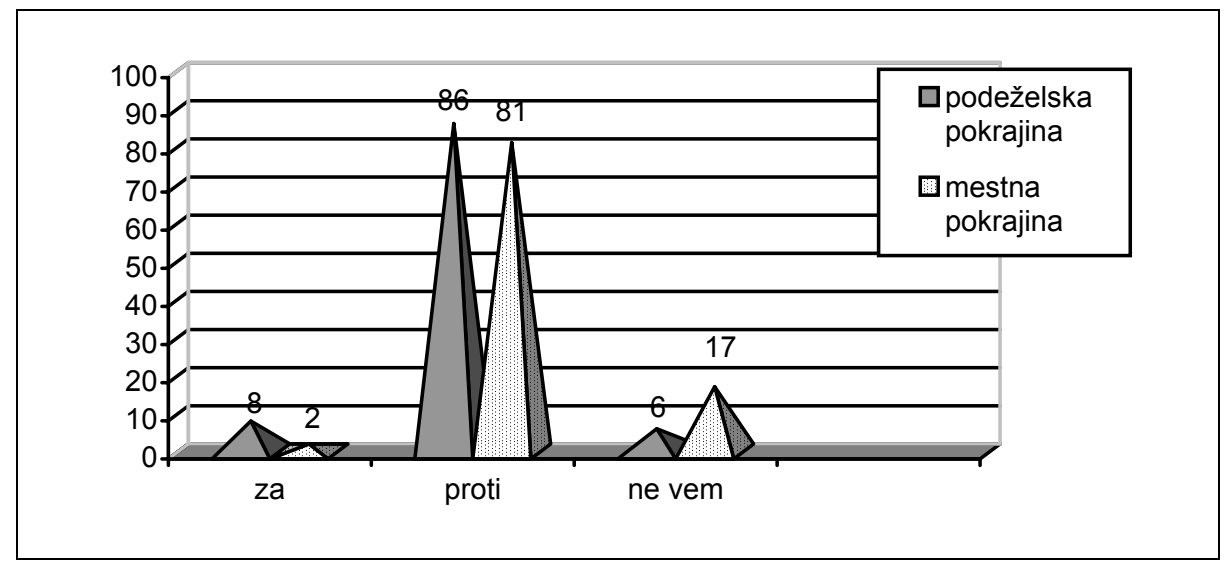


Osmim prebivalcem urbanih predelov ter enemu na podeželju je bilo vseeno, kaj se bo zgodilo z zalogami surovinskega vira.

Ocenjujemo, da so se anketirani prebivalci potencialno ugrezninskega območja $\mathrm{v}$ obeh, tako urbani kot podeželski pokrajini, podobno odzivali na predlagani odkop surovinskega vira, ker bi predviden poseg prizadel vse.

\subsection{Odnos prebivalcev do poselitvenih pokrajinskih virov}

Prebivalcem smo v anketnem vprašalniku ponudili možnost izbire lastnega okolja bivanja. $54 \%$ vprašanih iz podeželskih gospodinjstev je zavrnilo spremembo bivalnega okolja (B. O.), $25 \%$ pa bi jih v vsakem primeru izbralo možnost uporabe poselitvenih virov na območju Šaleške doline (Š.D.). Tudi v urbanih gospodinjstvih se največji delež anketirancev ne bi strinjal s preselitvijo (62 \%), $12 \%$ pa se jih je opredelilo za možnost bivanja kjerkoli v dolini. $\mathrm{V}$ obeh tipih naselij je presenetil visok delež prebivalcev, pripravljenih na izselitev iz doline; podeželska pokrajina $17 \%$, urbana $19 \%$. Sklepamo, da je zanje obstoječa stopnja degradacije, vključno s potencialno ogroženostjo bivalnega okolja, že presegla mejno kakovost, ki so jo prebivalci še pripravljeni sprejeti. Neopredeljenih je bilo $4 \%$ na podeželju in $7 \%$ v mestni pokrajini.

Diagram 3: Odziv prebivalcev na možnost izbire lastnega bivalnega okolja

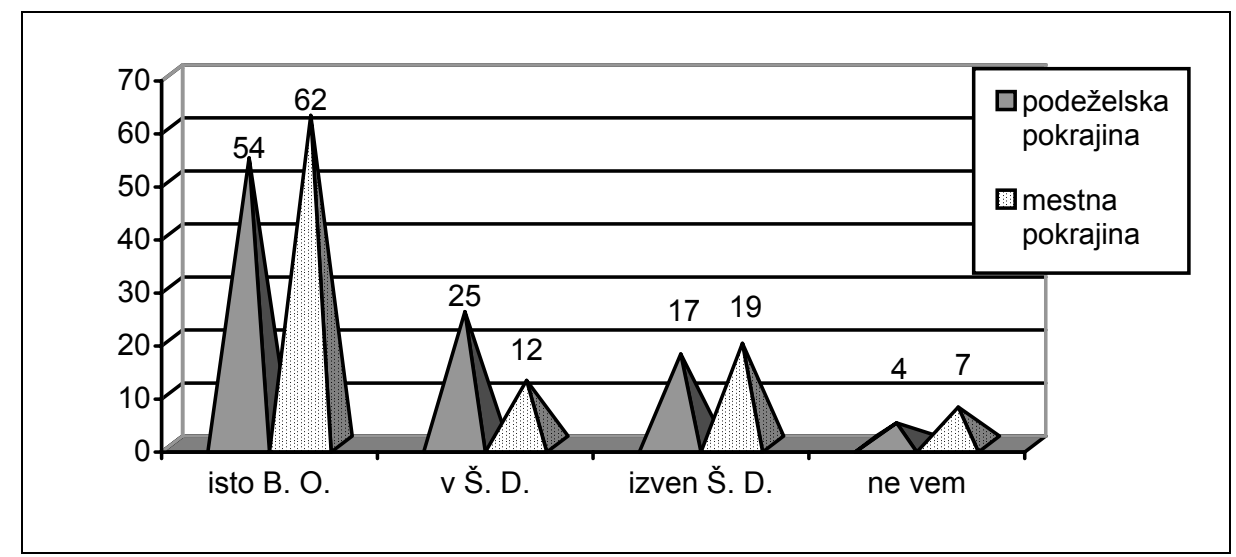

\subsection{Odnos prebivalcev do rekreacijsko-turističnih pokrajinskih virov}

Ugotavljali smo značilnosti prostočasnih dejavnosti prebivalcev. Po pričakovanjih se najpogosteje (vsakodnevno) rekreirajo mestni prebivalci (62 \%), 
manj na podeželju (35 \%). Trikrat tedensko izkorišča možnosti rekreacijskoturističnih virov $19 \%$ mestnega in $33 \%$ podeželskega prebivalstva, medtem ko občasno (redko) uporablja tovrstne pokrajinske vire slaba tretjina (32\%) v podeželskih naseljih in $19 \% \mathrm{v}$ mestnih.

Razlike so tudi v vrsti prostočasnih dejavnosti. Medtem ko na podeželju prevladujejo sprehod, hoja, obisk sorodnikov in prijateljev ter obdelovanje vrta, se pri mestnih prebivalcih pojavljajo še drugačne oblike rekreiranja (tenis, smučanje, jahanje), ki se večinoma odvijajo izven območja raziskave.

Podatki prikazujejo precejšnjo razpoložljivost rekreacijsko-turističnih virov v obravnavanem pokrajinsko-ekološkem sistemu, tako za urbano kot za podeželsko prebivalstvo.

Diagram 4: Pogostost uporabe rekreacijsko-turističnih pokrajinskih virov

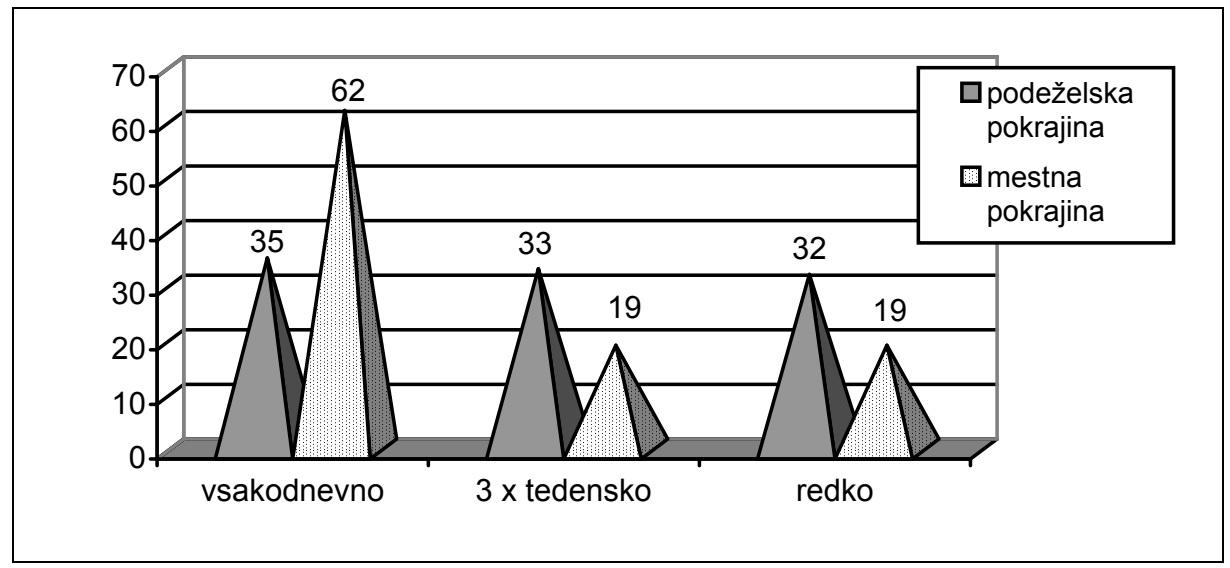

\subsection{Vrednotenje odnosa prebivalcev do nekaterih potencialno degradiranih pokrajinskih virov obravnavanega območja}

Mnenju in odnosu prebivalcev proučevanega pokrajinsko-ekološkega sistema smo s pomočjo vrednostne lestvice pripisali določen pomen. Vrednosti smo oblikovali na podlagi deležev (v odstotkih) posameznih odgovorov. Kjer so bili vsi pokrajinski viri obravnavani skupaj (poglavje 1.1.), velja vrednostna lestvica $1(*)$, pri posamični obravnavi pokrajinskih virov pa smo deleže odgovorov razvrstili v lestvico vrednosti 2.

Anketirani prebivalci obravnavane podeželske in mestne pokrajine so najvišjo vrednost in s tem največji pomen določili surovinskemu viru. Naslednja pokrajinska vira po pomembnosti, ki bi ju nadaljnje krčenje lignitnih zalog 
degradiralo, sta po mnenju vprašanih poselitveni in gospodarski pokrajinski vir. Po pripisanih vrednostih sledijo rekreacijsko-turistični in ekološki pokrajinski viri, katerih raba je večkrat možna istočasno. Najmanjšo vrednost in pomen so prebivalci obravnavanih pokrajin namenili prebivalstvenim in infrastrukturnim pokrajinskim virom. Gledano na splošno, je mestno prebivalstvo ocenjevalo pokrajinske vire $\mathrm{z}$ višjimi vrednostmi $(3,3 \mathrm{oz}$. s kategorijo $"$ pomemben« do »srednje pomemben«) kot podeželsko (2,6 oz. s kategorijo »manj pomemben« do »pomemben«).

Preglednica 1: Vrednotenje pomena pokrajinskih virov na območju raziskave (po mnenju prebivalcev leta 1999)

\begin{tabular}{|c|c|c|c|c|}
\hline \multicolumn{2}{|c|}{ pokrajinski viri } & $\begin{array}{c}\text { podeželska } \\
\text { pokrajina }\end{array}$ & $\begin{array}{c}\text { mestna } \\
\text { pokrajina }\end{array}$ & $\begin{array}{c}\text { SKUPAJ } \\
\text { (povprečna ocena } \\
\text { pomembnosti } \\
\text { posameznega vira) }\end{array}$ \\
\hline \multirow[b]{2}{*}{ naravni } & surovinski & 5 & 5 & 5 \\
\hline & $\begin{array}{l}\text { ekološki } \\
\text { (voda, zrak, tla)* }\end{array}$ & 2 & 3 & 2,5 \\
\hline \multirow{5}{*}{ družbeni } & prebivalstveni* & 1 & 2 & 1,5 \\
\hline & poselitveni & 3 & 4 & 3,5 \\
\hline & gospodarski* & 4 & 3 & 3,5 \\
\hline & infrastrukturni* & 1 & 2 & 1,5 \\
\hline & $\begin{array}{l}\text { rekreacijsko- } \\
\text { turistični }\end{array}$ & 2 & 4 & 3 \\
\hline \multicolumn{2}{|c|}{$\begin{array}{l}\text { SKUPAJ (povprečna ocena } \\
\text { pomembnosti vseh pokrajin. virov) }\end{array}$} & 2,6 & 3,3 & 2,9 \\
\hline
\end{tabular}

\begin{tabular}{|c|c|c|}
\hline $\begin{array}{c}\text { *Vrednostna } \\
\text { lestvica 1 (v \%) }\end{array}$ & Vrednost/ocena & $\begin{array}{c}\text { Vrednostna } \\
\text { lestvica 2 (v \%) }\end{array}$ \\
\hline $50<$ & $5=$ zelo pomemben & $75<$ \\
\hline $30-49$ & $4=$ srednje pomemben & $60-74$ \\
\hline $20-29$ & $3=$ pomemben & $40-69$ \\
\hline $10-19$ & $2=$ manj pomemben & $20-39$ \\
\hline$<9$ & $1=$ nepomemben & $<20$ \\
\hline
\end{tabular}

\section{SKLEP}

Ohranjanje pokrajinske pestrosti in podobe kulturne pokrajine, ki je med pomembnejšimi cilji sonaravnega in trajnostnega načrtovanja razvoja posameznega pokrajinsko-ekološkega sistema, je po Plutu (1999) tesno odvisno od okolju prilagojenega gospodarjenja $\mathrm{z}$ naravnimi viri. 
Sodbe o okolju v navezanosti na obe bazični prvini človekovega funkcioniranja - bivanje in delo, so pokazale, da je treba razmere v okolju resno upoštevati, saj zdravo ali onesnaženo okolje ne prizadeva le ožjega območja in tamkajšnjega prebivalstva, temveč vpliva na odločitve o migracijski dejavnosti v širši regiji oziroma preselitvi bivalnega in delovnega okolja iz nekega območja ali vanj (Ira, Kollar, 1992).

Obravnavano območje je že pod pritiskom potencialne ogroženosti, saj sta skoraj dve tretjini poselitvenih pokrajinskih virov tako v podeželski kot $\mathrm{v}$ mestni pokrajini dajali vtis o stagnaciji oz. je bilo opaziti malo obnavljanja. Kljub temu smo opazili več prenavljanja poselitvenih virov oz. novograjenih hiš v podeželski - $39 \%$ oz. $22 \%$ v mestni pokrajini. Sklepamo, da se prebivalci na podeželju počutijo manj ogrožene zaradi večje oddaljenosti od območja aktivnega odkopavanja v pridobivalnem prostoru premogovnika Velenje.

V kategorijo kmetij kot tipa bivališča se uvršča 34,7 \% anketiranih gospodinjstev na podeželju (17 kmetij), v urbanih naseljih pa 4,1 \%. Podatek nas opozarja, da bi načrtovana degradacija pokrajinskih virov tega območja pomenila precejšnjo izgubo, še posebej z vidika gospodarskih (kmetijskih) pokrajinskih virov.

Kot najpomembnejšo možno posledico, ki bi jo nadaljnje odkopavanje lignita povzročilo obravnavani pokrajini, so prebivalci mestne pokrajine izpostavili krčenje surovinskega vira (vrednost 5) in takoj za njim degradacijo poselitvenih in rekreacijsko-turističnih pokrajinskih virov, ki so ju ovrednotili z oceno 4. Z oceno "pomemben« (3) so ovrednotili ekološke in gospodarske vire, kot »manj pomembne« (ocena 2) pa opredelili prebivalstvene in infrastrukturne pokrajinske vire. Kategorije »nepomemben« (vrednost 1) niso uporabili.

Tudi vprašani na podeželju so najvišjo vrednost in pomen pripisali surovinskemu viru (vrednost 5). Nadalje so bili mnenja, da bi bili naslednji potencialno najbolj prizadeti pokrajinski viri gospodarski (vrednost 4), saj je njihovo bivalno okolje v 17 primerih (kmetije) istočasno tudi delovno. Sledijo poselitveni pokrajinski viri z oceno 3 (»pomemben«). Med »manj pomembne« (vrednost 2) uvrstijo ekološke in rekreacijsko-turistične vire, nepomembni (vrednost 1) pa se jim zdijo prebivalstveni in infrastrukturni pokrajinski viri.

Zakonski predpisi Evropske zveze ter ostalih mednarodnih dokumentov o dostopu javnosti do informacij obvezujejo države, da v razumljivi obliki zagotavljajo podatke o okolju, virih in razvoju posameznih pokrajinsko-ekoloških sistemov. Torej anketirani prebivalci upravičeno zahtevajo sodelovanje in vključevanje pri poseganju v njihovo bivalno okolje. Zanima jih kvaliteta njihovega bivalnega in delovnega okolja, saj je ekološko osveščena javnost eden temeljnih pogojev za trajnostno sonaravni okoljski, družbeni in gospodarski regionalni razvoj. 


\section{Literatura:}

Agenda 21,1992. The United Nations Conference on Environment and Development, Rio de Janeiro.

Ira, V., Kolar, D., 1992. Cognition of Environment as Part of the Relationship »Man-Environment«. Geographica Slovenica 23. Ljubljana, Inštitut za geografijo Univerze Edvarda Kardelja v Ljubljani.

Kladnik, D. s sod., 2001: Geografija, leksikon, Učila International, Tržič.

Kokole, V1., Kokole, Ve., 1998. Geografija Slovenije. Slovenska matica v Ljubljani, 310.

Medmrežje. E-novice UMANOTERA 073/02, Tedenske novice s področja varstva okolja in narave, UMANOTERA, Slovenska fundacija za trajnostni razvoj, ustanova. 25. 10. 2002.

Mikulik, O., Buček, A., Špes, M., 1989. Geografska proučevanja življenjskega okolja (teoretično-metodološki pristop), Geographica Slovenica 20. Ljubljana, Inštitut za geografijo Univerze Edvarda Kardelja v Ljubljani.

Nacionalni program varstva okolja (NPVO), 1999.

Plut, D., 1996. Osnovni kazalci kakovosti mestnega okolja z vidika trajnostnega sonaravnega razvoja. V: Geografski vestnik 68, Ljubljana, 247-257.

Plut, D., 1999. Pokrajinski vidiki sonaravnega razvoja zavarovanih območij Slovenskih Alp. Sonaravni razvoj v Slovenskih Alpah in sosedstvu.V: Dela 13, Oddelek za geografijo Filozofske fakultete v Ljubljani. Ljubljana, 103-114.

Plut, D., 2002. Geografija in sonaravno načrtovanje regionalnega napredka Zasavje. V: Geografija in njene aplikativne možnosti, Program in povzetki, Portorož, 97-98.

Priročnik o udeležbi javnosti v postopkih sprejemanja odločitev na področju varstva okolja. Sedanja praksa in možnosti razvoja v prihodnje; delovno gradivo. Slovensko predstavništvo Regionalnega okoljskega centra za Srednjo in Vzhodno Evropo, 1994.

Prosen, A., 1993. Sonaravno urejanje podeželskega prostora, Katedra za prostorsko planiranje na Fakulteti za arhitekturo, gradbeništvo in geodezijo, Ljubljana.

Strateške presoje vplivov regionalnih razvojnih programov na okolje, 2000. Evropska komisija, generalni direktorat za okolje.

Špes, M. 1998. Degradacija okolja kot dejavnik diferenciacije urbane pokrajine. Geographica Slovenica 30. Ljubljana, Inštitut za geografijo.

Taking Action, An Environmental Guide For You and Your Community, 1995. United Nations Environment Programme.

Vrišer, I. 1998. Uvod v geografijo. Ljubljana, FF, Oddelek za geografijo.

Uredba o vrstah posegov v okolje, 1996. Uradni list RS, št. 66, str. 5498. 


\section{RESPONSE OF INHABITANTS OF THE WESTERN PART OF THE ŠALEK VALLEY TO THE LANDSCAPE SOURCES}

\section{Summary}

There are over 50 mio tons of lignite under the surface of the western area of the Šalek Valley. In 1986, it was planned to be excavated. This plan was abandoned in January 2002. In 1999, we investigated the inhabitants' response to the landscape sources (natural; environmental, material and socioeconomic; demographic, settlement, economic, infrastructure, recreation-tourist) of the potentially impacted area (their living and working environment). The area extends over the urban landscape of Soštanj town and also rural landscape of the two nearest settlements - Florjan and Topolšica.

15-year period of uncertainty resulted in some specific sociogeographic concequences in the landscape and its sources. The moratorium of the reparation of settlement sources was noticed almost in two thirds of the surveyed area.

The potentially affected people of the study area responsed to the planned excavation ibn almost uniform manner: $81 \%$ of the inquired people from the urban area and $86 \%$ from the rural landscape were strictly against the project. They were aware of the impacts, which such a landscape degradation may have to all of the landscape sources.

The inhabitants of the rural landscape think that the intervention will have the strongest impact on the material and economic landscape sources (they are much more dependent on the land source; however, the urban inhabitants warned on the potential degradation of the settlements and recreationtourist landscape sources as well.

The evaluation of the inhabitants' response (from their own point of view) revealed that the urban population cares more for the whole landscape sources as the rural one, which evaluated demographic and infrastructure sources as »not important« (value 1). 